ного зварного шва (типове завдання) майстром виробничого навчання та групи кваліфікованих і не кваліфікованих робітників.

В ході роботи були побудовані гістограми довжини дуги на основі графіків, отриманих під час тренувальних сеансів. Проводилося обчислення основних статистичних характеристик, які дозволяють судити про характерні особливості варіаційного ряду в цілому. Найбільш часто використовуваними статистичними показниками параметрів зварювання є: середнє арифметичне, середнє квадратичне відхилення, дисперсія, коефіцієнт варіації. Побудовано графіки експериментальної функції розподілу. В даний час проводиться аналіз отриманих даних та розробляється математична модель, що дозволить відслідковувати та оцінювати індивідуальний прогрес зварника при навчанні 3 метою оптимізації навчального процесу.

\title{
Література:
}

1. Дідківський Р.М., Чвертко Є.П., Шевченко М.В., Пірумов А.С., Проценко П.П. Аналіз стану кваліфікаційних заходів з атестації зварників в Україні. Технологические системы. 2019. № 1(86). С. 19-23.

DOI https://doi.org/10.30525/978-9934-588-79-2-1.26

\section{ВЛИЯНИЕ НАПРАВЛЕНИЯ И ВЕЛИЧИНЫ ПОДАЧИ НА ДЕМПФИРУЮЩИЕ СВОЙСТВА ПРОЦЕССА ФРЕЗЕРОВАННИЯ КОНЦЕВЫМИ ФРЕЗАМИ}

\author{
Дядя С. И. \\ кандидат технических наук, доцент, \\ заведующий кафедрой технологии машиностроения \\ Национального университета «Запорожская политехника» \\ Козлова Е. Б. \\ кандидат технических наук, \\ дочент кафедры технологии машиностроения \\ Наџионального университета «Запорожская политехника» \\ Козлов М. Д. \\ магистр \\ Национального университета «Запорожская политехника», \\ г. Запорожье, Украина
}

Колебания, возникающие при концевом фрезеровании, связанные как с ударами при врезании зуба фрезы, так и с процессом резания, 
негативно влияют на стойкость инструмента, работу узлов станка, качество детали. Особенно это проявляется при фрезеровании с автоколебаниями. Для снижения этого влияния используют различные технологические приемы, уменьшающие силовое воздействие, конструктивные особенности инструмента. При этом одним из технологических решений может быть выбор величины и направления подачи. Как известно подача влияет на толщину срезаемого слоя [1], с увеличением которой увеличиваются демпфирующие свойства процесса резания. Следует отметить, что при концевом фрезеровании толщина сечения срезаемого слоя на всей длине фрезерования не постоянная. Она меняется при встречном фрезеровании от наименьшего значения до наибольшего, а при попутном, наоборот, от наибольшего до наименьшего (рис. 1) [2]. При этом, следует отметить, что в зоне профилирования обработанной поверхности, независимо от направления подачи, толщина срезаемого слоя всегда минимальная.

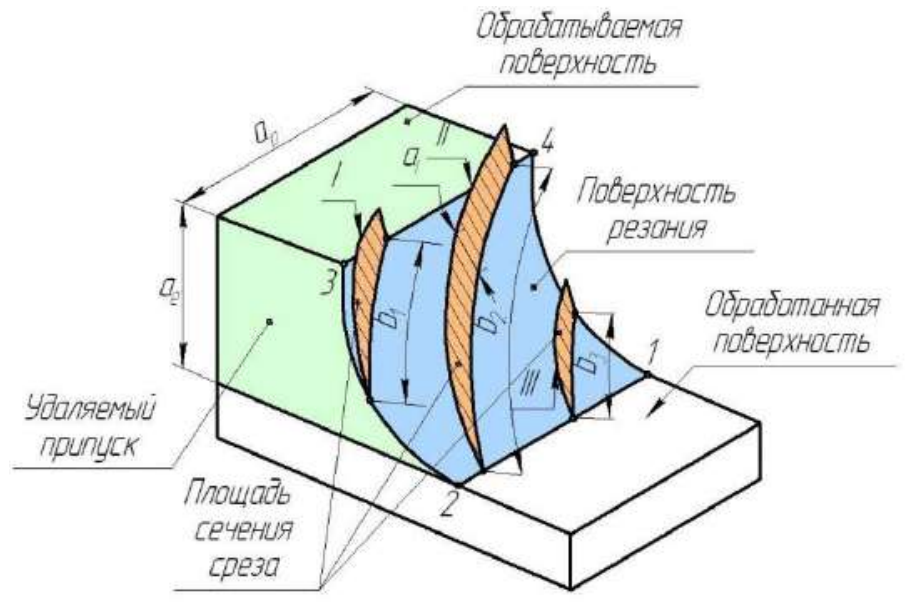

Рис. 1. Схема изменения толщины срезаемого слоя: встречное фрезерование: $\mathbf{a}$ - от 0 до $\max$; b - от 0 - max - 0, попутное фрезерование: $\mathbf{a}$ - от $\max$ до $0 ; \mathbf{b}$ - от 0 - max - 0

Для анализа демпфирующих свойств подачи были проведены исследования при встречном и попутном фрезеровании экспериментальной однозубой фрезой $\varnothing 30$ мм на специальном стенде [3]. Режимы резания принимались для условий фрезерования с автоколе-

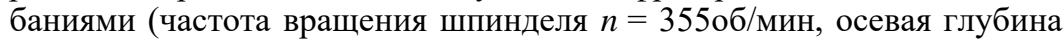


$\mathrm{a}_{\mathrm{p}}=0,5 \mathrm{мм}$, радиальная глубина $a_{e}=0,5$ мм, подачи $S_{z}=0,1$; 0,2 мм/зуб). При резании записывались осциллограммы колебаний детали.

На рис. 2 представлены фрагменты осциллограмм колебаний детали при встречном и попутном фрезеровании с указанным размахом автоколебаний - $R_{2}$ в зоне профилирования, величина которого характеризует демпфирующие свойства процесса резания [4].

Встречное фрезерование

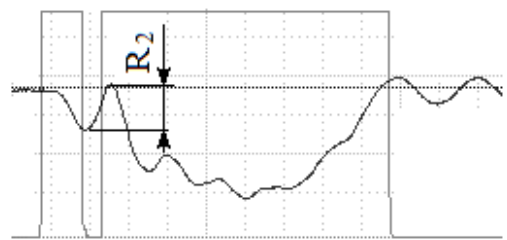

$$
S_{z}=0,1 \mathrm{mM} / \mathrm{oб}
$$

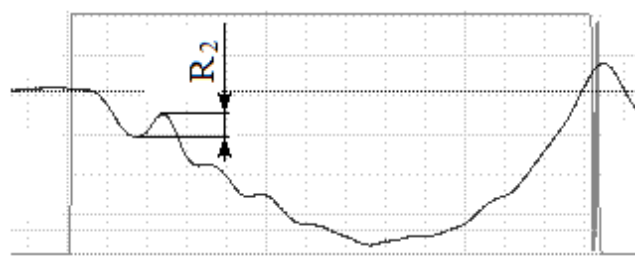

$$
S_{z}=0,2 \text { мм/об }
$$

Попутное фрезерование
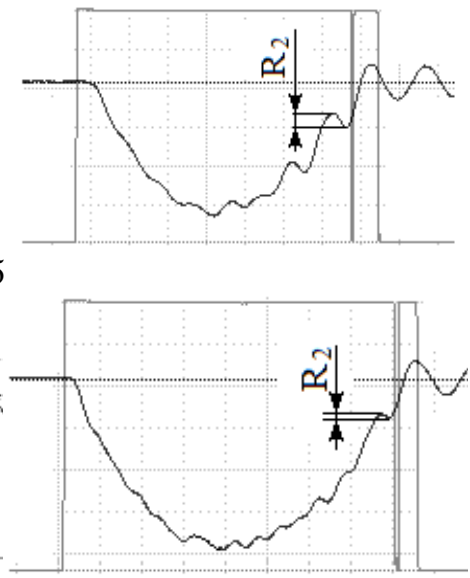

\section{Рис. 2. Фрагменты осциллограмм колебаний детали при встречном и попутном концевом фрезеровании}

Как видно из фрагментов осциллограмм, размах автоколебаний неодинаков от врезания инструмента и до его выхода из детали. Он имеет наибольшие значения в местах с наименьшей толщиной срезаемого слоя, как при встречном фрезеровании (при врезании), так и при попутном (при выходе зуба фрезы). С увеличением подачи амплитуда автоколебаний уменьшается. Следует отметить, что за счет изменения толщины срезаемого слоя от наибольшего значения до наименьшего при попутном фрезеровании амплитуда автоколебаний на выходе меньше, чем при встречном фрезеровании, когда фреза сразу врезается в минимальную толщину. В табл. 1 приведены значения размаха 
автоколебаний при встречном и попутном концевом фрезеровании с различными значениями подач.

Таблица 1

Размах автоколебаний $R_{2}$, мкм

\begin{tabular}{|c|c|c|}
\hline $\begin{array}{c}\text { Величина подачи, } \\
\boldsymbol{S}_{z}, \mathbf{м м} / \mathbf{3 у б}\end{array}$ & $\begin{array}{c}\text { Встречное } \\
\text { фрезерование }\end{array}$ & $\begin{array}{c}\text { Попутное } \\
\text { фрезерование }\end{array}$ \\
\hline 0,1 & 56 & 29 \\
\hline 0,2 & 33 & 7,9 \\
\hline
\end{tabular}

Следует отметить, что автоколебания с размахом 30-40 мкм благоприятны для процесса стружкообразования и стойкости инструмента [5]. Как показывают данные табл. 1 такие значения и меньшие характерны для попутного фрезерования.

Проведенные исследования показывают, что и встречное и попутное фрезерование обладают демпфирующими свойствами. Это подтверждается изменением интенсивности автоколебаний в процессе резания. В силу специфики процесса фрезерования интенсивность при попутном фрезеровании в 2 раза меньше чем при встречном.

С увеличением подачи увеличивается толщина срезаемого слоя, что также способствует снижению уровня автоколебаний.

Однако, следует отметить, что увеличение подачи ограничивается прочностью зуба инструмента. Поэтому при фрезеровании с автоколебаниями предпочтение следует отдавать попутному направлению подачи.

\section{Литература:}

1. Барабашов Ф.А. Фрезерное дело. М.: Высш. школа, 1973. 280 с.

2. Мазур М.П., Внуков Ю.М., Доброскок В.Л., Залога В.О., Новосьолов Ю.К., Якубов Ф.Я. Основы теории резания материалов: підручник / під заг. ред. М.П. Мазура. Львів : Новий світ - 2000, 2010. 422 с.

3. Внуков Ю.Н., Логоминов В.А., Каморкин П.А. Стенд для изучения механических колебаний при фрезеровании маложестких деталей при концевом фрезеровании. Резание и инструмент в технологических системах. Харьков: НТУ «ХПИ», 2011. Вып. 80. С. 32-37.

4. Внуков Ю.Н., Дядя С.И., Козлова Е.Б., Логоминов В.А., Черновол Н.Н. Автоколебания при фрезеровании тонкостенных элементов деталей: монография / под ред. Ю.Н. Внукова. Запорожье: ЗНТУ, 2017. 208 c.

5. Жарков И.Г. Вибрации при обработке лезвийным инструментом. Л.: Машиностроение, 1986. 184 с. 